Diabetologia 5, 25-28 (1969)

\title{
Glucose Intolerance in Uraemia
}

\section{Plasma Growth Hormone and Glueagon Values}

\author{
G. Tchobroutsky, G. Rosselin, R. Assan and M. Derot
}

Clinique du Diabète sucré et des Maladies de la Nutrition (Pr. M. Derot) Groupe de Recherche U. 55 de 1'Tnstitut National de la Santé et de la Recherche Médicale (Dr. G. Rosselin), Hôtel-Dieu, Place du Parvis Notre-Dame, Paris $4^{\circ}$ - France

Received: March 26, 1968

Summary. This study confirms our first results showing large and prolonged insulin secretion in patients with azotaemia and glucose intolerance. It shows that the pattern of growth hormone and glucagon secretions was not modified in these well nourished patients with chronic renal diseases and hyperazotaemia: the fasting values were in the normal range and the response during a $5 \mathrm{~h}$ glucose tolerance test was normal, except in one man with Fabry's disease, in whom a very large increase in plasma growth hormone was observed at the beginning of the GTT when the blood glucose increased. There was no increase in plasma H.G.H. during the intravenous glucose tolerance test of $60 \mathrm{~min}$. Plasma glucagon values were normal. - This study done on 11 subjects shows that the diminished tolerance to glucose observed in azotaemic patients in presence of a large and prolonged insulin secretion cannot be related to abnormalities in growth hormone or glucagon secretion.

Intolérance au glucose dans l'urémie. II. Valeurs plasmatiques de l'hormone de croissance et du glucagon

Résumé. Cette étude confirme nos premiers résultats démontrant une sécrétion d'insuline importante et prolongée chez des patients présentant une azotémie élevée et une intolérance au glucose. Elle montre que les carac. téristiques des sécrétions d'hormone de croissance et de glucagon ne sont pas modifiées chez ces patients bien nourris qui présentent des maladies rénales avec hyperazotémie: les valeurs à jeun sont dans les limites normales et la réponse au cours d'un test de tolérance au glucose d'une durée de $5 \mathrm{~h}$ est normale, excepté chez un homme ayant une maladie de Fabry chez lequel une très importante augmentation de l'hormone de croissance dans le plasma a été observée au début du GTT lorsque le glucose du sang s'élevait. II n'y a pas d'augmentation d'hormone de croissance dans le plasma pendant le test de tolérance au glucose de $60 \mathrm{~min}$. Les valeurs du glucar gon plasmatique sont normales. - Cette étude effectuée sur 11 sujets montre que la diminution de la tolérance an glucose qui est observée chez les patients azotémiques en présence d'une sécrétion d'insuline importante et prolongée ne peut pas être mise en relation avec des ano. malies de sécrétion de l'hormone de croissance ou du glucagon.

Eingeschränkte Glucosetoleranz bei Urämie. II. Plasma. Spiegel von Wachstumshormon und Glucagon

Zusammenfassung: Die vorliegende Untersuchung be. stätigt unsere früheren Resultate, die bei Patienten mit Urämie und Störungen der Glucosetoleranz eine ausgeprägte und verlängerte Insulinsekretion zeigten. Sie ergibt ferner, daß das Verhalten der Sekretion von Wachstumshormon and Glueagon bei diesen Patienten mit chronischen Nierenerkrankungen, die sich in gutem Ernährungszustand befinden, nicht verändert war: Die Nüchternwerte lagen im Normbereich und während eines 5stündigen Glucosetoleranztestes kam es zu einer norma. len Reaktion, wenn man von einem Mann mit Fabry'scher Erkrankung absieht, bei dem zu Beginn des GTT während des Blutzuckeranstieges eine sehr starke Zunahme des Wachstumshormons festzustellen war. Während des ein. stündigen i.v. GTT stieg das Plasma H.G.H. nicht an. Die Plasma-Glucagonspiegel verhielten sich normal. Diese Untersuchungen an 11 Probanden zeigen, daß die verringerte Glucosetoleranz bei urämischen Patienten bei gleichzeitig verstärkter und verlängerter Insulinausschüttung nicht auf eine gestörte Sekretion von Wachs. tumshormon oder Glucagon zurückgeht.

Key-words: Diabetes, uraemia, growth hormone, glueagon, insulin.
The occurrence of glucose intolerance in patients with renal failure is now well known $[6-9,11,14-16$, $18,21,22,25,27,28]$. We have shown that the insulin secretion is important and prolonged in azotaemic subjectssubmitted to oral glucose tolerance tests [25]. These results were confirmed by others $[6,7,9]$. Despite the large insulin secretion no reactive hypoglycaemia was observed in the late phase of the oral glucose tolerance test. This might suggest that there is also a high secretion of growth hormone and/or glucagon in patients with uraemia. We have studied 11 new uraemic subjects in respect to growth hormone and glucagon secretion.

\section{Methods}

Six men and five women were studied. All were well-nourished, chronically hyperazotaemic subjects (blood urea nitrogen above $100 \mathrm{mg} / \mathrm{p} .100 \mathrm{ml}$ ). They were between 20 and 67 years old, with a mean of 45 . None were obese. There was no family history of diabetes or obesity. Seven were submitted to an oral glucose tolerance test (GTT) by giving them $45 \mathrm{~g}$ of glucose per $\mathrm{m}^{2}$. On 5 subjects a rapid intravenous glucose tolerance test $\left(25 \mathrm{~g}\right.$ per $\left.\mathrm{m}^{2}\right)$ was performed, and three of them received a simultaneous injection of $2 \mu \mathrm{g} / \mathrm{kg}$ of glucagon. One arginine infusion test $(25 \mathrm{~g}$ in $400 \mathrm{ml} \mathrm{H} \mathrm{H}_{2} \mathrm{O}$ in $30 \mathrm{~min}$ ) was also performed. 
Blood glucose was determined by the glucose oxidase method [12] using Boehringer commercial kits (C.F. Boehringer \& Soehne GmbH., Mannheim). Plasma insulin, growth hormone (H.G.H.) and glucagon were estimated by the BERSON and YALOW radioimmunological method [4], as first employed for insulin [29], with small modifications used in our laboratory and previously described for insulin [19, 20], H.G.H. [24], and glucagon [2]. The standard now used for H.G.H. is the purified preparation of Prof. A.E.
The pattern of plasma growth hormone does not seem to be modified in these hyperazotaemic subjects. No high, fasting values were observed, except in patient LEC ... A secondary increase in plasma H.G.H. was seen in 5 out of 7 subjects during the $5 \mathrm{~h}$ GTT. An initial small increase, probably non-specific, was seen in 2 patients. A good response to arginine was observed in the one case studied. During the intravenous glucose tolerance test only one secondary increase in plasma H.G.H. was observed, probably because of the dimin-

Table 1. Oral glucose tolerance tests performed on seven azotaemic patients:

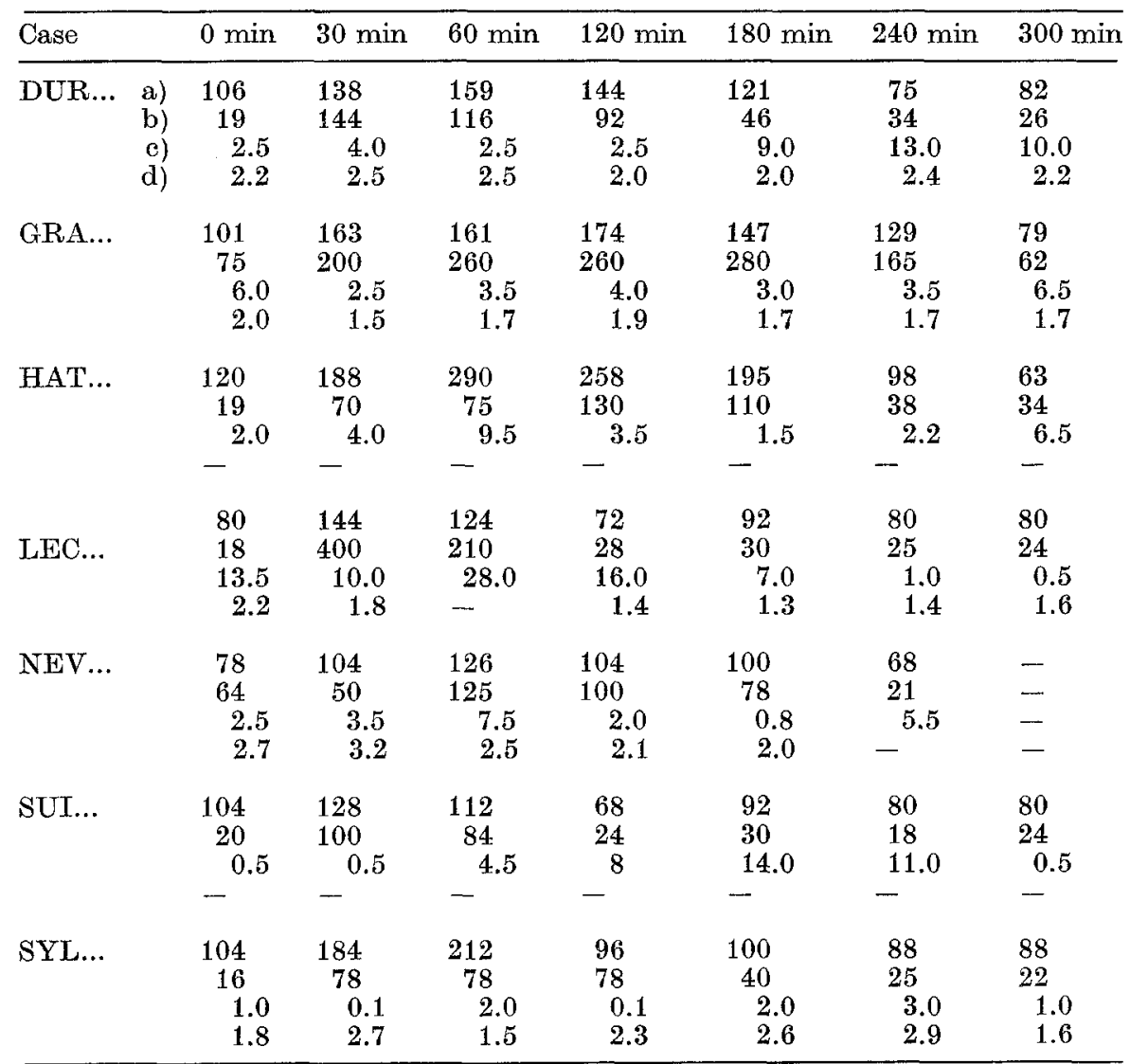

a) first value: blood glucose in $\mathrm{mg}$ per $100 \mathrm{ml}$

b) second value: plasma insulin in $\mu \mathrm{u} / \mathrm{ml}$

c) third value: plasma H.G.H. in $n g / m l$

d) fourth value: plasma glucagon in $n g / m l$

WIIHELmi (Atlanta, Georgia) HS 705 (2 I.U./mg). HS 705 is biologically and immunologically twice as potent as HS $545 \mathrm{~A}$, a preparation we have previously used [24].

\section{Results and Comments}

The levels of blood glucose, of plasma insulin, of plasma growth hormone, and of glucagon following a glucose tolerance test are given in Table 1. During the intravenous glucose tolerance test the results obtained are given in Table 2 . ished rate of glucose disappearance and the short period of observation (Table 2 ).

There was no hypersecretion of H.G.H. which could be responsible for the apparent resistance to insulin.

In only one subject (LEC...) was a very special pattern in H.G.H. secretion observed during the glucose tolerance test. Plasma H.G.H. was very high before the glucose tolerance test, and a large rise occurred during the first hour after the glucose load. It may have been due to a non-specific increase in plasma H.G.H., since it can occur spontaneously in normal 
adolescents [13] or in normal, fasting adults [17], [10]. Patient LEC... had Fabry's disease [5, 23]. In this inherited, systemic metabolic disease (glycolipid lipidosis), characterized by an accumulation of two or more and prolonged ${ }^{1}$ in azotaemic subjects submitted to oral glucose tolerance test, a fact also confirmed by others $[6,7,9]$.

This study also shows that the glucose intolerance

Table 2. Rapid intravenous glucose tolerance tests on five azotaemic patients:

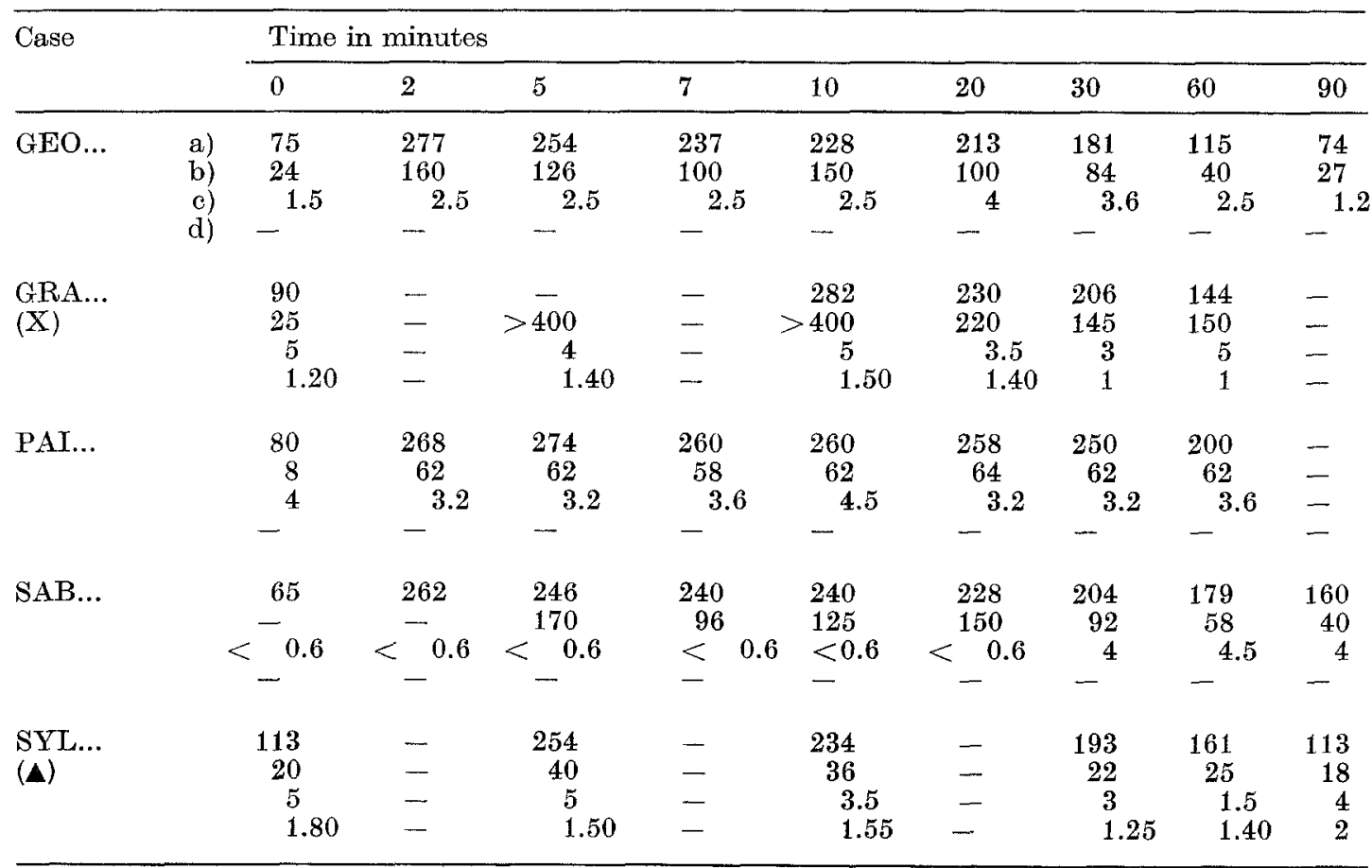

Cases $G E O \ldots, P A I \ldots$ and $S A B \ldots$ received simultaneously $2 \mu$ glucagon per $\mathrm{kg}$ body

weight, and the I. V. glucose.

Symbols $(X)$ and $(\mathbf{\Lambda})$ indicate subjects also submitted to oral $G T T$

(Table 1):

a) first value: blood glucose in $\mathrm{mg}$ per $100 \mathrm{ml}$

b) second value: plasma insulin in $\mu u / m l$

c) third value: plasma H.G.H. in $n g / m l$

d) fourth value: plasma glucagon in $\mathrm{ng} / \mathrm{ml}$

neutral glycolipids in the tissues, hypothalamic deposits were described [23]. It may be speculated that in this subject the rise in plasma H.G.H. one hour after glucose may be related to hypothalamic disorders, since it was observed in two adults with acromegaly and in one child with an optic glioma that encroached upon the hypothalamus [3]. In patient LEC... a com. plete autopsy was not available, and no answer can be given to this hypothesis.

The plasma glucagon values were in the normal range in the fasting period, and during GTT or the other investigations (Table 1 and 2)

\section{Discussion}

This study done on 11 subjects with chronic renal deficiency confirms our first study [25], which has shown that the insulin secretion is generally considerable observed in patients with renal failure cannot be related to elevated plasma levels of growth hormone or glucagon either at fast or after a glucose load.

The actual mechanism(s) of the diminished tolerance to glucose in hyperazotaemia remains unknown. We have reviewed elsewhere [26] the current hypotheses

1 In our laboratory normal values (means \pm sem) for blood glucose (BG) and plasma insulin (I) determined on 31 adults of both sexes during a 5 hour oral GTT were:

\begin{tabular}{|c|c|c|c|c|c|c|c|}
\hline Time & $\begin{array}{l}0 \\
\min \end{array}$ & $\begin{array}{l}30 \\
\min \end{array}$ & $\begin{array}{l}60 \\
\min \end{array}$ & $\begin{array}{l}120 \\
\mathrm{~min}\end{array}$ & $\begin{array}{l}180 \\
\text { min }\end{array}$ & $\begin{array}{l}240 \\
\min \end{array}$ & $\begin{array}{l}300 \\
\text { min }\end{array}$ \\
\hline $\begin{array}{l}\mathrm{BG} \\
\mathrm{mg} / 100 \mathrm{ml}\end{array}$ & $\begin{array}{l}84.7 \\
\pm \\
1.6\end{array}$ & $\begin{array}{c}127.0 \\
\pm \\
4.0\end{array}$ & $\begin{array}{c}122.5 \\
\pm \\
4.3\end{array}$ & $\begin{array}{l}96.8 \\
\pm \\
\overline{3} .5\end{array}$ & $\begin{array}{l}81.5 \\
\pm \\
\overline{3} .0\end{array}$ & $\begin{array}{l}80.1 \\
\pm \overline{2} .8\end{array}$ & $\begin{array}{l}81.1 \\
\pm \\
2.0\end{array}$ \\
\hline $\begin{array}{l}\text { I } \\
\mu u / \mathrm{ml}\end{array}$ & $\begin{array}{l}13.0 \\
\pm \\
1.0\end{array}$ & $\begin{array}{l}68.7 \\
\pm \\
7.1\end{array}$ & $\begin{array}{l}74.0 \\
\pm \\
7.7\end{array}$ & $\begin{array}{l}51.7 \\
\pm \\
5.0\end{array}$ & $\begin{array}{l}25.1 \\
\pm \\
\frac{1}{3.5}\end{array}$ & $\begin{array}{c}13.3 \\
\pm \\
1.8\end{array}$ & $\begin{array}{c}8.7 \\
\pm \\
0.5\end{array}$ \\
\hline
\end{tabular}


which have been advanced through publications. If one accepts that a certain degree of insulin resistance must be present, it cannot be due to a large, abnormal secretion of H.G.H. or glucagon as shown here, nor to an increase in plasma free fatty acids $[9,11]$, nor to acidosis [15], nor to abnormal concentrations of $\mathrm{Na}^{+}$or $K^{+}$in serum $[15,21]$. One study has shown improvement in glucose tolerance after administration of potassium and correction of the intra-cellular depletion of this ion [22]. The role of urea is very conflicting according to the contradictory studies: some accept $[6,14,16]$, whereas others deny $[11,18,27,28]$ its responsibility in glucose intolerance. But "one might consider that even the elevated levels of insulin found in azotaemic subjects were inadequate to meet the response demanded by the elevated glucose levels; that is, the pancreatic response to the degree of hyperglycaemia present should have been even greater" [7].

In fact, two studies have shown a greater pancreatic secretion after dialysis $[1,11]$. But the concept of pancreatic deficiency fails to account for the pronounced insulin response to intravenous tolbutamide $[7,25]$, despite the delayed nadir in blood glucose.

\section{References}

1. Almeey, A.C., K.E. Sussman, and J.H. Hotmes: Changes in glucose and insulin metabolism induced by dialysis in patients with chronic uremia. Metabolism 16, $733-740$ (1967).

2. Assan, R., G. Rosselin, J. Drouet, J. Dolats, G. TChobrovtsky et M. Derot: Dosage radioimmunologique du glucagon plasmatique chez l'homme. Résultats préliminaires. Ann. Fndoer. 27, $690-695(1966)$.

3. Beck, P., M.L. Parker, and W.H. Daughaday: Paradoxical hypersecretion of growth hormone in response to glucose. J. clin. Endocr. 26, 463-469 (1966).

4. Berson, S.A., R. S. Yalow, S.M. Gliok, and J. Rotr: Immunoassay of protein and peptides hormones. Metabolism 13, 1135-1153 (1964).

5. Brady, R.O., A.E. Gal, R.M. Bradley, E. MarTENSSON, A. L. WARSHAW, and L. LASTER: Enzymatic defect in Fabry's disease. New Engl. J. Med. 276, 1163-1167 (1967).

6. Briggs, J.D., K.D. BuChanaN, R.G. LukE, and M.T. Mc KrDDIE: Role of insulin in glucose intolerance in uraemia. Lancet $1967 \mathrm{I}, 462-464$.

7. CerdetTy, J.M, and N.H. ENGBRING: Azotemia and glucose intolerance. Ann. Int. Med. 66, 1097-1108 (1967).

8. CoHen, B.D.: Abnormal carbohydrate metabolism in renal disease. Blood glucose unresponsiveness to hypoglycemia, epinephrine and glucagon. Ann. Int. Med. 57, 204 (1962).

9. Fankhauser, S., et J.P. Fmiber: Les pertuxbations du métabolisme des hydrates de carbone dans l'azotémie chronique. Journées Annuelles de Diabétologie - Hôtel-Dieu 1966. 1 vol., p. 91-100. Paris: Flammarion Ed. Méd.

10. GLrok, S.M., and S. Goldsmrth: The physiology of growth hormone secretion. International Symposium on Growth Hormone - Excerpta Medica International Congress series $n^{\circ} 142$ p. 5. Amsterdam: Excerpta Medica Foundation.

11. Hanpers, C.L., J.S. Somidner, P.B. Doak, and J.P. MERrim: Effect of chronic renal failure and hemodialysis on carbohydrate metabolism. J. clin. Invest. 45, 1719-1731 (1966).

12. HugGeT, A.S.G., and D.A. Nixon: Use of glucose oxidase, peroxidase and 0-dianisidine in the determination of blood and urine glucose. Lancet 1957 II, 368.

13. Hunter, W.M., and W.M. RtGax: The diumal pattern of plasma growth hormone concentration in children and adolescents. J. Endocr. 34, 147-153(1966).

14. Hutchings, R. H., R.M. Hegstrom, and B.H. SCRIBNER: Glucose intolerance in patients on long-term intermittent dialysis. Ann. Int. Med. 65, 275-285 (1966).

15. LUKE, R.G., A.J. Dinwoodie, A.L. Linton, and A.C. KENNEDy: Fructose and glucose tolerance in uremia. J. Lab. clin. Med. 64, 731-740 (1964).

16. PerkofF, G.T., C.L. Thomas, J.D. Newton, J.C. SetclmaN, and F.Z. TYLER: Mechanism of impaired glucose tolerance in uremia and experimental hyperazotemia. Diabetes 7, 375 (1958).

17. Quabbe, H.J., E. Sohiluing, and H. HexGE: Pattern of growth hormone secretion during a 24-hour fast in normal adults. J. clin. Endocr. 26, $1173-1177$ (1966).

18. Reubi, F., H. PaUli et A. Teuscher: Quelques apsects du retentissement circulatoire, respiratoire et métabolique de l'insuffisance rénale. Actual. Néphr. Hop. Necker - 1 vol. Flammarion Ed. Méd. 1963.

19. Rosselin, G., R. Assan, R.S. YAlOW, and S.A. BERsor: Separation of antibody bound and unbound peptide hormone labelled with iodine 131 by talcum powder and precipitated silica. Nature 212, 355-357 (1966).

20. - G. Thhobrounsizy, R. Assan, J. Drovet, J. DoLAIs, P. Freyoret et M. Df́rot: La méthode radioimmunologique d'étude des hormones protéiques de Berson et Yatow. Ann. Endocr. 26, 449-464 (1965).

21. SAGTrD, U.: Glucose tolerance in acute ischemic renal failure. Acta med. scand. 172, 405 (1962).

22. Sperger, G., S.J. Bletoher, M. Goldberk, J. AdesMAN, and M.G. GOLDNER: The effect of potassium in the impaired glucose tolerance in chronic uremia. Metabolism 16, 581-585 (1967).

23. Sweeley, C.C., and B. Ktronsky: Glycolipid lipidosis: Fabry's disease. In: The metabolic basis of inherited disease - Edited by Stanbury, J.B., J.B. Wrataarden, and D.S. Freoriokson. 1 vol. 2 nd Ed. p. $618-632$. N.Y. Mo Graw-Hill 1966.

24. Tchobroutsix, G., G. Rosseltr, R. Assan, J. Drouet et M. DÉrot: Dosage radio-immunologique de l'hormone somatotrope humaine (H.G.H.) Revue Franc. Etudes Clin. Biol. 10, 651-657 (1965).

25. - G. Connin de L'Hortet, G. Rossetity, R. Assan, et M. Denor: Etude de la glycorégulation dans l'insuffisanee rénale chronique. Diabetologia 1, $101-$ $108(1965)$.

26. - - B. Gillts, G. Rosselin, R. Assan, P. Freychet et M. Dézor: Métabolisme du glucose dans l'insuffisance rénale - Journal d" Urologie et de Néphrologie 74 293-309 1968.

27. Teuscher, A., R. Fankfauser, u. F.R. Kuffer: Untersuchungen zum Kohlenhydratstoffwechsel bei Niereninsuffizienz. Klin. Wsohr, 41, 706-715 (1963).

28. Westervelt, F.B., and G.E. Schreiner: The carbohydrate intolerance of uremic patients. Ann. Int. Med. $57,266-276(1962)$.

29. YAtow, R.S., and S.A. Berson: Immunoassay of endogenous plasma insulin in man. J. clin. Invest. 39, $1157-1175(1960)$.

Dr. G. TCHOBRoutsky

Clinique du Diabète sucré

Hôtel-Dieu

Place du Parvis Notre Dame

F. 75 Paris $4 \mathrm{e}$, France 